\title{
Regulacje prawne w zakresie opieki okołoporodowej w Polsce w kontekście projektu nowego standardu organizacyjnego
}

\section{Wprowadzenie}

Zgodnie z art. 68 ust. 3 Konstytucji Rzeczpospolitej Polskiej ${ }^{1}$ kobieta w ciąży i okresie okołoporodowym objęta jest szczególną troską ze strony Państwa. W związku z powyższym ustanowienie i stosowanie standardów opieki okołoporodowej należy uznać za niezbędne zwłaszcza wtedy, gdy kobiety znajdujące się w podobnej sytuacji klinicznej są poddawane postępowaniu medycznemu w różny sposób i z różnymi efektami. Z tego właśnie powodu niezwykle istotne wydaje się wskazanie jednolitych, powszechnie obowiązujących standardów w celu poprawy jakości udzielanych świadczeń oraz przestrzegania fundamentalnych praw należnych kobietom i ich dzieciom w opiece okołoporodowej.

W efekcie wieloletniej pracy interdyscyplinarnego Zespołu Ekspertów powołanego przez Ministra Zdrowia Z. Religę, z dniem 19 października 2012 r. weszło w życie rozporządzenie wprowadzające Standardy Opieki Okołoporodowej w Polsce (dalej „Standardy”), będące trzecią (po brytyjskiej i hiszpańskiej) regulacją tego rodzaju w Europie ${ }^{2}$. W pracach zespołu brali czynny udział przedstawiciele ginekologów-położników,

${ }^{1}$ Konstytucja Rzeczypospolitej Polskiej z dnia 2 IV 1997 r. (Dz.U. Nr 78, poz. 483 ze zm.), dalej „Konstytucja RP”.

${ }^{2}$ Rozporządzenie Ministra Zdrowia z dnia 20 IX 2012 r. w sprawie standardów postępowania medycznego przy udzielaniu świadczeń zdrowotnych z zakresu opieki okołoporodowej sprawowanej nad kobietą w okresie fizjologicznej ciąży, fizjologicznego porodu, połogu oraz opieki nad noworodkiem (Dz.U. poz. 1100). 
neonatologów, położnych, a także Narodowy Fundusz Zdrowia (NFZ), Ministerstwo Zdrowia oraz - jako przedstawiciele strony społecznej członkowie Fundacji Rodzić po Ludzku³. Podstawą prac nad treścią Standardów były również wytyczne Światowej Organizacji Zdrowia (ang. World Health Organization, WHO) oraz zasady medycyny opartej na dowodach naukowych, które zostały dostosowane do systemu ochrony zdrowia w Polsce. Standardy zostały wydane w formie aktu normatywnego powszechnie obowiązującego o randze rozporządzenia. Wprowadzony standard miał stanowić rodzaj gwarancji, że w stosunku do pacjentki w okresie ciąży fizjologicznej, porodu fizjologicznego oraz połogu nie będą podejmowane żadne medycznie nieuzasadnione czynności. Przede wszystkim jednak przepisy Standardów miały stanowić zbiór podstawowych praw pacjentek, które w przypadku nieprzestrzegania przez personel medyczny mogą być prawnie egzekwowane.

Prawo do właściwej opieki okołoporodowej oraz godnego porodu stanowi realizację podstawowych praw pacjenta oraz poszanowanie fundamentalnych praw człowieka. Biorąc pod uwagę, jak ważnym i wyjątkowym wydarzeniem dla życia i psychiki każdej kobiety jest urodzenie dziecka, racjonalny ustawodawca powinien ukształtować regulacje prawne w zakresie opieki okołoporodowej w ten sposób, by każda kobieta na terenie kraju mogła urodzić dziecko w godnych warunkach, otoczona opieką i szacunkiem.

Jak wynika z przeprowadzonych badań i raportów sporządzonych przez niezależne od siebie podmioty, pomimo obowiązywania Standardów prawa kobiet w zakresie opieki okołoporodowej nie zawsze są respektowane. Konieczność wprowadzenia zmian w obowiązujących Standardach, zwłaszcza w zakresie zapewnienia prawnych gwarancji ich przestrzegania, była podnoszona zarówno przez pacjentki, jak i organizacje pozarządowe je wspierające. Niestety, planowane zmiany w zakresie opieki okołoporodowej, które mają wejść w życie z dniem 1 stycznia 2019 r., nie zawierają rozwiązań prawnych, które przyczyniłyby się do poprawy rzeczywistego stosowania Standardów przez placówki położnicze. Ponadto zmiana formy standardów opieki okołoporodowej wzbudza liczne wątpliwości natury prawnej, zwłaszcza w zakresie formy ich obowiązywania.

${ }^{3}$ Uzasadnienie do Rozporządzenia Ministra Zdrowia z dnia 20 IX 2012 r. w sprawie standardów postępowania medycznego przy udzielaniu świadczeń zdrowotnych z zakresu opieki okołoporodowej sprawowanej nad kobietą w okresie fizjologicznej ciąży, fizjologicznego porodu, połogu i opieki nad noworodkiem. 
Cel niniejszego opracowania stanowi omówienie obowiązujących regulacji prawnych z dziedziny opieki okołoporodowej, wskazanie ich zakresu przedmiotowego i podmiotowego oraz dokonanie analizy prawnej projektu nowego rozporządzenia. Podstawą rozważań jest przedstawienie charakteru prawnego standardów opieki okołoporodowej. Niezwykle ważna jest próba uzyskania odpowiedzi na pytanie, czy zasady wiedzy medycznej powinny zostać wydane w formie standardów postępowania medycznego, stanowiących akt normatywny powszechnie obowiązujący, czy też powinny stanowić niewiążące prawnie wytyczne i zalecenia. Ponadto na uwagę zasługuje zagadnienie znaczenia standardów opieki okołoporodowej w kontekście obowiązku stosowania aktualnej wiedzy medycznej i postępowania z należytą starannością. Zwieńczenie pracy stanowi szczegółowa analiza projektu nowych standardów oraz przedstawienie postulatów de lege ferenda, zwłaszcza w zakresie gwarancji prawnych przestrzegania standardów opieki okołoporodowej w Polsce.

\section{Charakter prawny standardów opieki okołoporodowej}

Do podstawowych obowiązków podmiotów świadczących opiekę okołoporodową, a w szczególności lekarza, należy postępowanie zgodnie $\mathrm{z}$ aktualną wiedzą medyczną. Personel medyczny jest zobowiązany do przestrzegania standardów ustalających optymalne postępowanie medyczne w praktyce klinicznej. W związku z powyższym niezbędne wydaje się udzielenie odpowiedzi na pytanie, czy wytyczne ekspertów oraz zasady wiedzy medycznej powinny zostać zapisane $\mathrm{w}$ formie odpowiednio sformalizowanych standardów postępowania medycznego, czy też powinny obrać kształt prawnie niewiążących zaleceń.

Na wstępie należy wskazać, że pojęcie standardu nie ma definicji legalnej w polskim systemie prawnym, zwłaszcza w prawie medycznym. Ogólne, powszechne rozumienie pojęcia standardu oznacza normy określające podstawowe wymagania stawiane czemuśt ${ }^{4}$ W kontekście prawa medycznego standard to przeciętny model, norma, wzorzec, profesjonalnie uzgodniony poziom wykonawstwa jakiegoś działania, stosownie do potrzeb grupy pacjentów, który jest osiągalny, mierzalny, pożądany. Jest tym wzorcem, do którego aktualna praktyka jest porów-

${ }^{4}$ Hasło "Standardy", Słownik języka polskiego PWN, https://sjp.pwn.pl/sjp/standardy;3061827.html (dostęp: 21 VII 2018). 
nywana ${ }^{5}$. Tematyka standardów medycznych skierowanych do określonej grupy jej beneficjentów może dotyczyć między innymi wskazań co do metod diagnostycznych, zapobiegawczych, pielęgnacyjnych, leczniczych oraz kontroli procesu leczniczego.

Zarówno w doktrynie prawa, jaki w środowisku medycznym istnieją znaczne rozbieżności dotyczące tego, czy zasady wiedzy medycznej z zakresu opieki okołoporodowej powinny zostać sformalizowane w postaci standardów postępowania stanowiących powszechnie obowiązujący akt normatywny. Część społeczności medycznej zajmuje stanowisko, że wprowadzenie standardów nie przyczyni się do poprawy sytuacji pacjentek, dzieci poczętych i noworodków, a w szczególności nie zminimalizuje liczby błędów popełnianych przez lekarzy i personel medyczny, zwłaszcza w czasie porodu 6 . Grupa, która stoi w wyraźnej opozycji wobec obowiązywania standardów postępowania medycznego jako aktu prawnego, jest Naczelna Rada Lekarska. Z drugiej jednak strony liczne środowiska, z Fundacją Rodzić po Ludzku na czele, argumentuja, że standardy $w$ formie reguł postępowania medycznego powinny obowiązywać właśnie w tym kształcie ze względu na bezpieczeństwo ich beneficjentów, a także dlatego, że zwykle jakość świadczenia zdrowotnego jest bezpośrednio związana z odgórnie ustalonymi standardami postępowania, zwłaszcza w niepublicznych zakładach opieki zdrowotnej. Podnoszony jest również argument, że standardy postępowania medycznego z zakresu opieki okołoporodowej, będące aktem powszechnie obowiązującym, stanowią najlepszy rodzaj gwarancji praw kobiet w okresie porodu, które zostały im przyznane w Konstytucji RP (art. 68 ust. 3) i które stanowią wyraz realizacji fundamentalnych praw pacjenta.

Standardy opieki okołoporodowej mogą przyjąć zarówno postać sformalizowana, o charakterze normatywnym, jak i funkcjonować jako tzw. soft law. W pierwszym z wymienionych przypadków standardy medyczne stanowią akt prawny, który w sposób jednolity obowiązuje na terenie całego kraju. Oznacza to, że tak wydane standardy obowiązują w sposób jednakowy we wszystkich placówkach medycznych w Polsce: i o charakterze publicznym, i niepublicznym. Standardy medyczne ujęte w formie regulacji prawnych są wiążące dla adresata, a każde odstępstwo od nich może skutkować konsekwencjami prawnymi: cywilnymi,

\footnotetext{
${ }^{5}$ A. Piątek, Standardy praktyki w zawodach pielegniarki i położnej, w: Podstawy organizacji pracy pielegniarskiej. Podręcznik dla studentów studiów licencjackich Wydziałów Pielęgniarstwa oraz Wydziałów Nauki o Zdrowiu, pod red. A. Ksykiewicz-Doroty, Lublin 2004, s. 186.

${ }^{6}$ B. Kamiński, Na marginesie reformy, standardów medycznych i Europejskiej Konwencji Bioetycznej - refleksje klinisty, "Prawo i Medycyna” 1999, nr 3, s. 109.
} 
karnymi, dyscyplinarnymi. W drugim przypadku pozanormatywne regulacje w zakresie opieki okołoporodowej mogą przyjąć kształt zaleceń i wytycznych, opracowywanych zazwyczaj pod kierunkiem wybitnych autorytetów medycznych, tj. przez ośrodki badawcze, towarzystwa naukowe, zespoły ekspertów, bądź też wypracowywanych przez powołane przez państwo niezależne podmioty o zasięgu krajowym (często przez Agencję Oceny Technologii Medycznych i Taryfikacji ${ }^{7}$ ). Tego rodzaju wytyczne nie daja prawnych gwarancji ich przestrzegania, nie są bezwzględnie obowiązujące. W większości przypadków ich respektowanie zależy wyłącznie od woli podmiotu, którego standardy dotyczą. Stosowanie standardów w formie zaleceń i wytycznych niebędących powszechnie obowiązującym prawem może powodować dla lekarzy i personelu medycznego brak dostatecznej ochrony przed ewentualnymi roszczeniami ze strony pacjentów. Dla pacjentek z kolei oznacza to brak aktu prawnego, na który mogłyby się powołać w sposób jednakowy we wszystkich placówkach medycznych na terenie kraju. Swego rodzaju wyjątek mogą stanowić wytyczne bazujące na aktualnej wiedzy medycznej, które są tworzone zgodnie z zasadami Evidence-Based Medicine, stanowiącymi niezwykle ważne w codziennej praktyce medycznej wskazówki merytoryczne ${ }^{8}$. Stosowanie tych wytycznych jest prawnym obowiązkiem lekarza, gdyż jest podstawą postępowania zgodnego z aktualnym stanem wiedzy medycznej.

Standardy postępowania mogą również zostać wydane przez NFZ, który jest uprawniony narzucić wybór konkretnego sposobu pracy podczas wykonywania kontraktowych świadczeń opieki zdrowotnej. Ponadto, na podstawie art. $23 \mathrm{w}$ zw. z art. 24 Ustawy z dnia 15 kwietnia 2011 r. o działalności leczniczej ${ }^{9}$, każdy członek personelu medycznego jest zobowiązany w zakresie sposobu i warunków udzielania świadczeń zdrowotnych do postępowania zgodnego z regulaminem organizacyjnym danego podmiotu, a więc do poddania się standaryzacji wewnętrznej podmiotu leczniczego ${ }^{10}$.

${ }^{7}$ Agencja Oceny Technologii Medycznych i Taryfikacji (dawniej Agencja Oceny Technologii Medycznych) - państwowa jednostka organizacyjna posiadająca osobowość prawną, nadzorowana przez ministra właściwego do spraw zdrowia. Agencja pełni funkcje opiniodawczo-doradcze dla Ministra Zdrowia.

${ }^{8}$ Polski Instytut Evidence-Based Medicine, http://ebm.org.pl/show.php?aid=15267 \&_tc=68EB6C271784F100BCD58A017F07C790 (dostęp: 10 VII 2018).

9 Tekst jedn. Dz.U. 2018, poz. 160, dalej „u.d.1.”.

${ }^{10}$ D. Karkowska, Nowe standardy opieki nad matką i dzieckiem w kontekście prawnej opieki okołoporodowej w Polsce, Warszawa 2013, s. 9. 
W polskim systemie prawnym standardy świadczenia usług medycznych mogą być realizacją kompetencji ustawowych Ministra Zdrowia, który dotychczas na podstawie art. 22 ust. 5 u.d.l. mógł wydać rozporządzenie, kierując się potrzebą zapewnienia odpowiedniej jakości świadczeń, ustalając standardy postępowania medycznego w wybranych dziedzinach medycyny lub w określonych podmiotach wykonujących działalność leczniczą. Rozporządzenie określające standardy postępowania w opiece okołoporodowej musiało dotyczyć wyłącznie tych kwestii, które obejmuje upoważnienie ustawowe Ministra Zdrowia w u.d.l. i nie mogło przekraczać granic tego upoważnienia. Obecnie obowiązujące rozporządzenie w sprawie standardów postępowania medycznego jest niewątpliwie standardem medycznym o charakterze normatywnym, czyli częścią systemu powszechnie obowiązującego prawa.

Na podstawie kontrowersyjnej nowelizacji u.d.1. ${ }^{11}$ standardy postepowania medycznego zostały zastąipione standardami organizacyjnymi opieki zdrowotnej. Standardy organizacyjne opieki zdrowotnej dotyczą sposobu sprawowania opieki nad pacjentem lub wykonywania czynności związanych z udzielaniem świadczeń zdrowotnych (art. 22 ust. 4c u.d.l.). W świetle art. 41 noweli ustawy dotychczasowe przepisy wykonawcze wydane na podstawie art. 22 ust. 5 u.d.l. zachowują moc do dnia wejścia w życie przepisów wykonawczych wydanych na podstawie nowego upoważnienia ustawy, jednak nie dłużej niż do dnia 31 grudnia 2018 r. Oznacza to, że dotychczas wydane Rozporządzenie zostanie jedynie tymczasowo utrzymane w mocy, a kolejne akty wykonawcze wydane na podstawie znowelizowanego art. 22 ust. 5 u.d.l. będą ograniczały się do określenia standardów organizacyjnych opieki zdrowotnej w wybranych dziedzinach medycyny lub w określonych podmiotach wykonujących działalność leczniczą. Stosownie do art. 22 ust. 4 b u.d.l. podmiot wykonujący działalność leczniczą przy udzielaniu świadczeń zdrowotnych będzie zobowiązany stosować standardy organizacyjne opieki zdrowotnej, jeżeli zostały one określone dla dziedziny medycyny objętej zakresem świadczeń zdrowotnych udzielanych przez ten podmiot wykonujący działalność leczniczą lub dla rodzaju wykonywanej przez niego działalności leczniczej.

Przyjęcie w postaci aktu prawa powszechnie obowiązującego jedynie standardów organizacyjnych, a zatem zakresowo odmiennych od standardów postępowania, w ocenie autorki może przyczynić się do utraty dorobku dobrych praktyk wypracowanych w tym zakresie przez personel

${ }^{11}$ Ustawa z dnia 10 VI 2016 r. o zmianie ustawy o działalności leczniczej oraz niektórych innych ustaw (Dz.U. poz. 960). 
i placówki medyczne, w których standardy postępowania medycznego są przestrzegane. Wątpliwości budzi zagadnienie, czy projekt nowego rozporządzenia dotyczącego standardu organizacyjnego w zakresie opieki okołoporodowej - który w swej treści zawiera schematy postępowania medycznego - może w sposób zgodny z techniką prawodawczą zostać wydany w formie standardów niebędących już standardami postępowania medycznego. W opinii autorki standardy opieki okołoporodowej zawierające wzorce postępowania medycznego powinny zostać wydane, jak miało to miejsce $\mathrm{w}$ reżimie prawnym przed nowelizacja, $\mathrm{w}$ formie standardów posteppowania medycznego o randze rozporządzenia.

Pozornie niewielka zmiana w przepisach prawnych może oznaczać wielką zmianę dla kobiet w Polsce. Nowelizacja u.d.l. spotkała się z ogromną krytyką m.in. ze strony pacjentek, organizacji pozarządowych oraz Rzecznika Praw Obywatelskich. Rzecznik podkreślił, że uchylenie dotychczas obowiązującego modelu standardów powoduje, iż realizacja wypracowanych już uprawnień kobiet będzie zależała od decyzji konkretnego lekarza w szpitalu ${ }^{12}$. W ocenie Rzecznika dokonana zmiana u.d.l. jest niezrozumiała i trudna do zaakceptowania, może bowiem w przyszłości niekorzystnie rzutować m.in. na prawa pacjentek przynależne kobietom ciężarnym i rodzącym ${ }^{13}$. Rzecznik podzielił niepokój środowiska pacjentek odnośnie do tego, że planowana zmiana może w znaczny sposób pogorszyć sytuację kobiet rodzących w Polsce $^{14}$.

\section{Znaczenie standardów opieki okołoporodowej w kontekście obowiązku stosowania aktualnej wiedzy medycznej i postępowania z należytą starannością}

Zgodnie z treścią art. 4 Ustawy z dnia 5 grudnia 1996 r. o zawodach lekarza i dentysty ${ }^{15}$ do podstawowych obowiązków lekarza należy postępowanie zgodnie $\mathrm{z}$ aktualną wiedzą medyczną ${ }^{16}$. Przepisy prawa

${ }^{12}$ Pismo Rzecznika Praw Obywatelskich Adama Bodnara do Ministra Zdrowia Konstantego Radziwiłła z dnia 13 II 2017 r., sygn. V.7010.102.2016.AA/EO.

${ }^{13}$ Ibidem.

${ }^{14}$ Ibidem.

15 Tekst jedn. Dz.U. 2018, poz. 617, dalej „u.z.l.”.

${ }^{16}$ Artykuł 4 u.d.1.: „Lekarz ma obowiązek wykonywać zawód, zgodnie ze wskazaniami aktualnej wiedzy medycznej, dostępnymi mu metodami i środkami zapobiegania, rozpoznawania i leczenia chorób, zgodnie z zasadami etyki zawodowej oraz z należytą starannością". 
odpowiadające art. 4 u.z.l. zostały zawarte również w innych ustawach regulujących zasady wykonywania zawodów medycznych, m.in. w art. 11 Ustawy z dnia 15 lipca 2011 r. o zawodach pielęgniarki i położnej ${ }^{17}$. Postępowanie zgodnie z aktualną wiedzą medyczną wynika także z prawa pacjentów do uzyskania odpowiedniej jakości świadczenia, które zapewnia Ustawa z dnia 6 listopada 2008 r. o prawach pacjenta i Rzeczniku Praw Pacjenta ${ }^{18}$. Zgodnie z powołaną regulacją fundamentalnym prawem pacjenta jest otrzymanie świadczeń zdrowotnych odpowiadających wymaganiom aktualnej wiedzy medycznej (art. 6 ust. 1 u.p.p.). Prawny nakaz stosowania aktualnej wiedzy medycznej można odnaleźć również w Ustawie z dnia 27 sierpnia 2004 r. o świadczeniach opieki zdrowotnej finansowanych ze środków publicznych ${ }^{19}$ oraz $\mathrm{w}$ przepisach rozporządzeń wydanych na podstawie delegacji $\mathrm{z}$ art. 22 ust. 4 a i 5 u.d.l.

W wykonywaniu zawodów medycznych bardzo ważne jest nieustanne kształcenie się, konieczność orientacji w aktualnym stanie wiedzy medycznej w trakcie uprawiania profesji lekarskiej ${ }^{20}$. Nakaz stałego poszerzania oraz stosowania aktualnej wiedzy lekarskiej został zawarty także w Kodeksie Etyki Lekarskiej ${ }^{21}$. Na wiedzę medyczną składają się: wiedza o metodach i środkach oraz umiejętność ich stosowania ${ }^{22}$. W świetle powyższego niezwykle ważne wydaje się wskazanie źródeł wiedzy medycznej, których przestrzeganie może być egzekwowane wobec personelu medycznego zarówno przez pacjentów, pracodawcę, jak i uprawnione organy państwowe.

Samo pojęcie aktualnej wiedzy medycznej nie ma definicji legalnej. Można jednak przyjąć, że aktualna wiedza medyczna to wiedza o sposobach postępowania medycznego, które zostały uznane na podstawie wyników poprawnie przeprowadzonych badań naukowych za rozwiązania optymalne z punktu widzenia bilansu korzyści i ryzyka związanego z ich stosowaniem $\mathrm{w}$ danym wskazaniu klinicznym ${ }^{23}$. Dlatego też

17 Tekst jedn. Dz.U. 2018, poz. 123.

18 Tekst jedn. Dz.U. 2017, poz. 1318, dalej „u.p.p.”.

19 Tekst jedn. Dz.U. 2017, poz. 1938.

${ }^{20}$ L. Ogiegło, Ustawa o zawodach lekarza i lekarza dentysty. Komentarz, komentarz do art. 4 u.d.l., Legalis, 2015.

${ }^{21}$ Kodeks Etyki Lekarskiej, https://www.nil.org.pl/_data/assets/pdf_file/0003/4764/ Kodeks-Etyki-Lekarskiej.pdf (dostęp: 8 IX 2018).

22 Ibidem.

${ }^{23}$ P. Najbuk, Znaczenie standardów postępowania dla odpowiedzialności prawnej lekarza, „Standardy Medyczne", http://www.standardy.pl/newsy/id/94 (dostęp: 21 VII 2018). 
uzasadnione jest twierdzenie, że pojęcie aktualnej wiedzy medycznej ma charakter obiektywny, nie jest uzależnione od subiektywnych przekonań personelu medycznego lub pacjenta w tym zakresie ${ }^{24}$.

Należy jednak zwrócić uwagę, że zastosowanie aktualnej wiedzy medycznej może napotkać liczne problemy w praktyce. Jako jeden z wielu przykładów można wskazać różne metody postępowania medycznego, które stosuje się w podobnych okolicznościach faktycznych, zgodnie $z$ aktualną wiedzą medyczną. Innym problemem są okoliczności, w których wiedza teoretyczna może w danej sytuacji znacznie wyprzedzać realną dostępność metod i środków. Ograniczenia dostępu do niektórych metod i środków mogą być spowodowane przeszkodami zarówno subiektywnymi (np. brak określonych umiejętności praktycznych), jak i obiektywnymi (np. względy ekonomiczne, organizacyjne, techniczne itp.). Ponadto, jak wskazuje wyrok Sądu Najwyższego (SN) z 28 października 1983 r., wyklucza się stosowanie metod i środków starych i nierokujących lub gorzej rokujących, jeżeli są one powszechnie zastępowane innymi metodami leczenia ${ }^{25}$. Lekarz zawsze musi bowiem działać co najmniej zgodnie z minimalnymi wymogami wynikającymi $z$ aktualnego stanu wiedzy medycznej ${ }^{26}$.

W kontekście prawnego obowiązku lekarza, jakim jest nakaz stosowania aktualnej wiedzy medycznej, niezwykle ważną rolę odgrywają ustalone standardy określonego postępowania. W odniesieniu do problematyki standardów opieki okołoporodowej, a w szczególności ich obecnej i przyszłej formy obowiązywania, kluczowe jest wyjaśnienie, jakie znaczenie mają standardy postępowania, które przybierają formę aktów wiążących prawnie bądź aktów niewiążących prawnie.

Znaczna liczba wytycznych, zaleceń oraz standardów nie jest prawnie wiążąca, jednakże odgrywa niepodważalną rolę w praktyce orzeczniczej przy ustalaniu, czy działanie lekarza spełnia przesłankę działania zgodnego z aktualną wiedzą medyczną. Często to właśnie na tej podstawie biegły sądowy w czasie procesu dokonuje kwalifikacji określonego postępowania personelu medycznego jako zachowania lege artis. Należy jednak zwrócić uwagę, że te standardy nie mogą być stosowane w sposób mechaniczny i bezrefleksyjny. Na ocenę postępowania leczniczego powinna wpływać indywidualna, konkretna ocena

${ }^{24}$ Ibidem.

${ }^{25}$ Wyrok SN z 28 X 1983 r., sygn. II CR 358/85, OSP 1984, nr 9, poz. 187, s. 467.

${ }^{26}$ E. Zielińska, Komentarz do art. 4 u.d.l., w: Ustawa o zawodach lekarza i lekarza dentysty. Komentarz, pod red. E. Barcikowskiej-Szydło i in., Warszawa 2014, s. 84. 
okoliczności faktycznych, np. nietypowy charakter danego przypadku, czy też konieczność zastosowania alternatywnych sposobów leczenia.

Ze względu na zmienny ze swej natury zakres pojęcia aktualnej wiedzy medycznej próba regulacji prawnej standardów medycznych w znacznej liczbie przypadków jest niezwykle trudna. Jednakże w niektórych sytuacjach klinicznych, będących wystarczająco powtarzalnymi, wprowadzono wiążące standardy postępowania w celu zapewnienia wysokiego poziomu opieki nad pacjentem, zgodnego z aktualną wiedzą medyczną. Dotychczas Minister Zdrowia wydał na podstawie art. 22 ust. 5 u.d.l. jedynie kilka rozporządzeń ustanawiających standardy medyczne w określonych dziedzinach medycznych. Poza standardami dotyczącymi opieki okołoporodowej standardy postępowania medycznego obowiązują również $\mathrm{w}$ dziedzinie anestezjologii i intensywnej terapii ${ }^{27}$; także one zostały wprowadzone na podstawie delegacji ustawowej $\mathrm{w}$ formie prawnie wiążącego rozporządzenia.

Na podstawie analizy obecnie obowiązującego rozporządzenia wprowadzającego standardy okołoporodowe należy stwierdzić, że zostały one sporządzone w sposób raczej szczegółowy, jednakże prawodawca, chcąc zapewnić niezbędną elastyczność przyjętych standardów okołoporodowych, zastosował zabieg legislacyjny polegający na wprowadzeniu odesłań w niektórych przypadkach do „aktualnych zaleceń". W świetle powyższego obecnie standardy okołoporodowe są uzupełniane i doprecyzowywane przez zalecenia wydawane przez uznane gremia naukowe. Dlatego też standardy okołoporodowe powinny być rozumiane jako wykaz niezbędnych świadczeń, które nie wykluczają udzielania innych dodatkowych świadczeń, jeżeli są one zgodne z aktualną wiedzą medyczną. Przyjęcie innej interpretacji byłoby sprzeczne z nakazem działania dla dobra pacjenta zgodnie $\mathrm{z}$ aktualną wiedzą medyczną ${ }^{28}$.

Poza bezwzględnym obowiązkiem przestrzegania przepisów prawa i zasad etyki zawodowej od lekarzy i położnych wymaga się również postępowania z należytą starannością ${ }^{29}$. Przez pojęcie zachowania należytej staranności, częściowo zdefiniowane w art. 355 Kodeksu cywilnego $^{30}$, należy rozumieć taki sposób postępowania, który odpowiada

${ }^{27}$ Rozporządzenie Ministra Zdrowia z dnia 16 XII 2016 r. w sprawie standardu organizacyjnego opieki zdrowotnej w dziedzinie anestezjologii i intensywnej terapii (Dz.U. poz. 2218).

${ }^{28}$ Ibidem.

${ }^{29}$ Artykuł 4 u.z.l. i art.11 ust. 1 u.p.p.

${ }^{30}$ Ustawa z dnia 23 IV 1964 r. Kodeks cywilny (tekst jedn. Dz.U. 2018, poz. 1025 ze zm.), dalej "k.c.". 
wymaganiom zawartym w obiektywnym wzorcu postępowania ${ }^{31}$. Jak wskazał Sąd Najwyższy w uzasadnieniu wyroku z 23 października 2003 r., "zastosowanie w praktyce [wzorca staranności - dop. Z.W.] polega najpierw na dokonaniu wyboru modelu, ustalającego optymalny w danych warunkach sposób postępowania, odpowiednio skonkretyzowanego i aprobowanego społecznie, a następnie na porównaniu zachowania się dłużnika $\mathrm{z}$ takim wzorcem postępowania. O tym, czy na tle konkretnych okoliczności można osobie zobowiązanej postawić zarzut braku należytej staranności w dopełnieniu obowiązków, decyduje nie tylko niezgodność jego postępowania z modelem, lecz także uwarunkowana doświadczeniem życiowym możliwość i powinność przewidywania odpowiednich następstw zachowania"32. Zdefiniowanie należytej staranności i wskazanie sytuacji jej niedołożenia ma decydujący wpływ na możliwość przypisania danej osobie odpowiedzialności cywilnej w wypadku, gdy opiera się ona na zasadzie winy. Wzorzec należytej staranności jest taki sam niezależnie od tego, czy odpowiedzialność danej osoby w stosunku prawnym uzależniona jest od zachowania przez niego należytej staranności, czy też wymaga zaistnienia rażącego niedbalstwa lub winy umyślnej ${ }^{33}$.

Oceniając należytą staranność w odniesieniu do personelu medycznego, należy wziąć pod uwagę profesjonalny charakter świadczonych usług. Dlatego też staranność wymagana od lekarza, pielęgniarki i położnej powinna być szczególnie wysoka, tj. mieć charakter standardu profesjonalisty wskazanego w art. $355 \S 2$ k.c. Należyta staranność w stosunku do lekarzy powinna być rozumiana jako obiektywnie istniejący wzorzec postępowania obowiązujący każdego lekarza w tym samym stopniu. Na podstawie analizy literatury przedmiotu ${ }^{34}$ oraz orzecznictwa sądowego ${ }^{35}$ można stwierdzić, że musi to być staranność wysokiego stopnia, oznaczająca, iż powstanie wypadku czy innego

${ }^{31}$ K. Osajda, Komentarz do art. 355 k.c., w: idem, Kodeks cywilny. Komentarz, Warszawa 2017.

${ }^{32}$ Wyrok SN z 23 X 2003 r., sygn. V CK 311/02, Legalis/el.; tak też uzasadnienie wyroku SN z 10 II 2010 r., sygn. V CSK 287/09, OSP 2012, nr 10, poz. 95 z glosą F. Śmigielskiego, s. 661-664, oraz wyrok SN z 5 V 2011 r., sygn. I PK 228/10, Legalis/el.

${ }^{33}$ Tak P. Machnikowski, Komentarz do art. 355, Nb 11, w: Kodeks cywilny. Komentarz, pod red. E. Gniewka, P. Machnikowskiego, Legalis/el. 2016.

${ }_{34}$ Zob. M. Nesterowicz, Prawo medyczne, Toruń 2016, s. 42 i n.

${ }^{35}$ Zob. np. wyrok Sądu Apelacyjnego (SA) w Białymstoku z 15 V 2015 r., sygn. I ACa 1077/14; wyrok SA w Warszawie z 4 IV 2015 r., sygn. I ACa 515/14; wyrok SA w Rzeszowie z 12 VI 2013 r., sygn. I ACa 134/13; wyrok SA w Warszawie z 10 III 2015 r., sygn. VI ACa 651/14. 
niekorzystanego dla pacjenta zdarzenia wyrządzającego mu szkodę było nie do uniknięcia nawet przez najbardziej przezornego, starannego i wykwalifikowanego lekarza. Dlatego też dla potrzeb prawa medycznego można stwierdzić, że działanie lub postępowanie z zasadą należytej staranności wymaga przestrzegania określonych sformalizowanych reguł medycznych, będących pochodną nauki i obecnego stanu wiedzy specjalistycznej, wiedzy racjonalnej, czyli zdroworozsądkowej i działania z odpowiednim zaangażowaniem swej uwagi, jakiego wymaga dana sytuacja ${ }^{36}$. Powyższe znajduje potwierdzenie w u.d.l., w której $\mathrm{w}$ art. 4 ustawodawca nakłada na lekarza obowiązek postępowania zgodnie z zasadą należytej staranności, mianowicie lekarz ma obowiązek wykonywać swój zawód zgodnie ze wskazaniami aktualnej wiedzy medycznej, dostępnymi mu metodami i środkami zapobiegania, rozpoznawania i leczenia chorób, zgodnie z zasadami etyki zawodowej oraz z należytą starannością. Podobnie Kodeks Etyki Lekarskiej w art. 8 wskazuje, że "lekarz powinien przeprowadzać wszelkie postępowanie diagnostyczne, lecznicze i zapobiegawcze z należytą starannością, poświęcając im niezbędny czas".

Brak dochowania należytej staranności może mieć dwojaki charakter - subiektywny albo obiektywny ${ }^{37}$. Subiektywne uchybienie polega na tym, że personel medyczny przy wykonywaniu danej czynności nie koncentruje się na tym, co czyni, nie stara się działać efektywnie. Jako przykład subiektywnych uchybień można wskazać takie zachowanie lekarza lub położnej, które może dotyczyć zarówno techniki medycznej (nieuwaga, lekceważenie, nieuzasadniony pośpiech, niewiedza, nieostrożność postępowania), jak i technik niemedycznych (m.in. porzucenie pacjentki, brak koniecznego nadzoru, odmowa udzielenia pomocy, niesprawowanie należytej opieki nad kobietą i jej dzieckiem, niepowiadomienie lekarza w sytuacji, gdy jest to konieczne $)^{38}$. Uchybienie należytej staranności w wersji obiektywnej oznacza, że lekarz lub położna poprzez swoje zachowanie narusza powszechnie obowiązujące przepisy (np. Standardy Opieki Okołoporodowej), reguły wynikające z zasad wiedzy medycznej i doświadczenia oraz deontologii zawodowej.

\footnotetext{
${ }^{36}$ M. Nesterowicz, op. cit., s. 87.

${ }^{37}$ D. Karkowska, op. cit. s. 32.

${ }^{38}$ Ibidem.
} 


\section{Zakres przedmiotowy i podmiotowy standardów opieki okołoporodowej}

W efekcie wieloletniej pracy zespołu ekspertów powołanego przez Ministra Zdrowia Z. Religę przyjęcie rozporządzania wprowadzającego standardy opieki okołoporodowej nastąpiło z dniem 20 września 2012 r. i weszło w życie z dniem 19 października 2012 r. Rozporządzenie zostało znowelizowane i obecnie obowiązuje w brzmieniu nadanym rozporządzeniem Ministra Zdrowia z dnia 16 września 2015 r. zmieniającym rozporządzenie w sprawie standardów postępowania medycznego przy udzielaniu świadczeń zdrowotnych z zakresu opieki okołoporodowej sprawowanej nad kobietą w okresie fizjologicznej ciąży, fizjologicznego porodu, połogu oraz opieki nad noworodkiem ${ }^{39}$. Rozporządzenie zawiera załącznik - Standardy postępowania, mający taką samą moc prawną jak przepisy Rozporządzenia.

Obowiązujące Standardy dotyczą postępowania medycznego w obrębie podmiotów wykonujących działalność leczniczą niezależnie od źródeł finansowania tychże świadczeń. Poza zakresem przedmiotowym Rozporządzenia pozostają porody domowe, które odbywają się na podstawie umów cywilnoprawnych, zawieranych z pacjentkami przez położne jako osoby fizyczne. Ustawodawca objął treścią Standardów wyłącznie ciążę fizjologiczną, tj. ciążę przebiegającą w sposób prawidłowy ${ }^{40}$. Prawa zawarte w Standardach przysługują wyłącznie pacjentkom rodzącym w sposób fizjologiczny, to znaczy gdy ich poród jest niskiego ryzyka od momentu rozpoczęcia i utrzymuje taki stopień ryzyka przez cały czas trwania porodu, w wyniku którego noworodek rodzi się z położenia główkowego, pomiędzy ukończonym trzydziestym siódmym a czterdziestym drugim tygodniem ciąży, i po którym matka i noworodek są w dobrym stanie. Uzasadniona konieczność ingerencji w naturalny proces ciąży lub porodu, w szczególności leczenie cukrzycy ciężarnej, znieczulenie farmakologiczne, poród zabiegowy, oznacza, że ciąża lub poród wymaga zastosowania dodatkowych procedur wykraczających poza treść Standardów ${ }^{41}$.

\footnotetext{
${ }^{39}$ Rozporządzenia Ministra Zdrowia z dnia 16 IX 2015 r. zmieniające rozporządzenie w sprawie standardów postępowania medycznego przy udzielaniu świadczeń zdrowotnych z zakresu opieki okołoporodowej sprawowanej nad kobietą w okresie fizjologicznej ciąży, fizjologicznego porodu, połogu oraz opieki nad noworodkiem (Dz.U. poz. 1514, tekst jedn. Dz.U. 2016, poz. 1132), dalej „Rozporządzenie”.

${ }^{40}$ Rozporządzenie Ministra Zdrowia z dnia 16 IX 2015 r., część I, pkt 2 ust. 5.

${ }^{41}$ Rozporządzenie Ministra Zdrowia z dnia 16 IX 2015 r., część I, pkt 3.
} 
Wprowadzone Standardy dotyczą wyłącznie fizjologicznego przebiegu ciąży, porodu i połogu. W świetle powyższego pojawiały się głosy zarówno personelu medycznego, jak i samych kobiet, że zasadniczą wadą Standardów jest to, iż nie mają zastosowania we wszystkich przypadkach, tj. w sytuacjach, gdy ciąża została zakończona w inny sposób niż poród fizjologiczny. Biorąc to pod uwagę, w dniu 2 czerwca $2016 \mathrm{r}$. weszło w życie Rozporządzenie Ministra Zdrowia z dnia 9 listopada 2015 r. w sprawie standardów postępowania medycznego przy udzielaniu świadczeń zdrowotnych w dziedzinie położnictwa i ginekologii z zakresu okołoporodowej opieki położniczo-ginekologicznej, sprawowanej nad kobietą w okresie ciąży, porodu, połogu, w przypadkach występowania określonych powikłań oraz opieki nad kobietą w sytuacji niepowodzeń położniczych ${ }^{42}$. Rozporządzenie dotyczy procedur postępowania w sytuacjach występowania określonych powikłań ciąży i porodu, takich jak: nadciśnienie tętnicze, poród przedwczesny, ciąża bliźniacza, zwiększone ryzyko niedotlenienia wewnątrzmacicznego płodu oraz krwotok położniczy. Rozporządzenie zawiera również standardy opieki nad kobietą w sytuacji niepowodzeń położniczych, to znaczy $\mathrm{m}$.in. poronienia lub urodzenia dziecka martwego, dziecka niezdolnego do życia bądź obarczonego letalnymi schorzeniami ${ }^{43}$.

Obecnie obowiązujące przepisy Rozporządzenia dotyczą standardów postępowania medycznego przy udzielaniu świadczeń zdrowotnych z zakresu opieki okołoporodowej sprawowanej nad kobietą w okresie fizjologicznej ciąży, fizjologicznego porodu, połogu oraz opieki nad noworodkiem. Standardy określają poszczególne elementy opieki medycznej mającej na celu uzyskanie dobrego stanu zdrowia matki i dziecka, przy ograniczeniu do minimum interwencji medycznych, w szczególności: amniotomii, stymulacji czynności skurczowej, podawania opioidów, nacięcia krocza, cięcia cesarskiego, podania noworodkowi mleka modyfikowanego, z uwzględnieniem zasad bezpieczeństwa zdrowotnego, w ramach których opieka opiera się na praktykach o udowodnionej skuteczności ${ }^{44}$. Zgodnie z postanowieniami Standardów ingerencja w naturalny proces ciąży, porodu i laktacji ma wiązać się wyłącznie z uzasadnionymi medycznie podstawami ${ }^{45}$. Realizacja praw pacjenta w przypadku sprawowania opieki nad kobietą w ciąży,

\footnotetext{
${ }^{42}$ Dz.U. poz. 2007.

${ }^{43}$ Treść tego Rozporządzenia nie stanowi przedmiotu niniejszego opracowania.

${ }^{44}$ Rozporządzenie Ministra Zdrowia z dnia 16 IX 2015 r., część I pkt 1.

${ }^{45}$ Rozporządzenie Ministra Zdrowia z dnia 16 IX 2015 r., część I pkt 3.
} 
porodu i połogu powinna polegać w szczególności na respektowaniu jej prawa do świadomego udziału w podejmowaniu decyzji związanych z porodem, obejmujaccych zakres procedur medycznych.

Obowiązujące Standardy składają się z czternastu części tematycznych: I. Postanowienia ogólne, II. Zalecany zakres świadczeń profilaktycznych i działań w zakresie promocji zdrowia oraz badań diagnostycznych i konsultacji medycznych, wykonywanych u kobiet w okresie ciąży, wraz z okresami ich przeprowadzania, III. Identyfikacja czynników ryzyka powikłań przedporodowych i śródporodowych, IV. Plan opieki przedporodowej i plan porodu, V. Postępowanie w trakcie porodu, VI. Strategie uśmierzania bólu w trakcie porodu, VII. Rozpoczęcie porodu, VIII. Postępowanie w I okresie porodu, IX. Postępowanie w II okresie porodu, X. Postępowanie w III okresie porodu, XI. Postępowanie w IV okresie porodu, XII. Opieka nad noworodkiem, XIII. Podstawy zabiegów restytucyjnych u noworodków, XIV. Połóg.

Standardy Opieki Okołoporodowej wskazują obowiązki osoby sprawującej opiekę nad rodzącą kobietą. Osoba sprawująca opiekę to lekarz specjalista w dziedzinie położnictwa i ginekologii lub położna, sprawujący odpowiednio opiekę nad ciężarna, rodząca, położnicą i noworodkiem ${ }^{46}$. Zgodnie z treścią Rozporządzenia ${ }^{47}$ podstawowe zadania osoby sprawującej opiekę obejmują w szczególności:

1. ocenę stanu rodzącej kobiety, płodu oraz noworodka;

2. wykrywanie i eliminowanie czynników ryzyka, rozwiązywanie problemów oraz wczesne wykrywanie patologii;

3. prowadzenie porodu przy użyciu technik wspierających jego naturalny mechanizm;

4. opiekę nad noworodkiem po urodzeniu;

5. zapewnienie opieki realizowanej przez specjalistów, jeżeli ujawnią się czynniki ryzyka lub pojawią powikłania uzasadniające takie działanie;

6. wsparcie rodzącej oraz jej osoby bliskiej w trakcie porodu oraz położnicy w okresie połogu.

Standardy Opieki Okołoporodowej wskazują zalecany zakres świadczeń profilaktycznych i działań w zakresie promocji zdrowia oraz badań diagnostycznych i konsultacji medycznych, które powinny być wykonywane u kobiet w ciąży. Podczas opieki przedporodowej

\footnotetext{
${ }^{46}$ Ponadto: lekarz ze specjalizacją I stopnia w dziedzinie położnictwa i ginekologii oraz lekarz w trakcie specjalizacji w dziedzinie położnictwa i ginekologii.

${ }^{47}$ Rozporządzenie Ministra Zdrowia z dnia 16 IX 2015 r., część I pkt 7.
} 
osoba sprawująca opiekę nad ciężarną ustala z ciężarną plan opieki przedporodowej oraz plan porodu obejmujaccy wszystkie elementy postępowania medycznego podczas porodu i miejsce porodu ${ }^{48}$. Ciężarna ma prawo do indywidualnego wyboru miejsca porodu w warunkach szpitalnych lub pozaszpitalnych, w których czuje się bezpiecznie i w których są udzielane świadczenia zdrowotne ${ }^{49}$. Ponadto ma możliwości wyboru osoby sprawującej nad nią opiekę spośród osób uprawnionych do jej sprawowania, z uwzględnieniem zasad organizacyjnych obowiązujących $\mathrm{w}$ miejscu udzielania świadczenia określonych w regulaminie organizacyjnym podmiotu wykonującego działalność leczniczą ${ }^{50}$.

Zgodnie z treścią Standardów Opieki Okołoporodowej rodzącą należy traktować z szacunkiem oraz umożliwić jej branie udziału w podejmowaniu świadomych decyzji związanych z porodem. Osoby sprawujące opiekę powinny nawiązać dobry kontakt z rodzącą i mieć świadomość, jak ważny jest ton rozmowy, ich postawa oraz słowa kierowane do rodzącej. Personel medyczny powinien pytać rodzącą o jej potrzeby i oczekiwania, a informacje $\mathrm{w}$ tym zakresie wykorzystać do wspierania i kierowania rodzącą $w$ czasie porodu ${ }^{51}$. Personel powinien szanować prywatność rodzącej i jej poczucie intymności ${ }^{52}$. Osoby sprawujące opiekę nad rodzącą powinny witać ją osobiście, przedstawić się i wyjaśnić swoją rolę w porodzie i opiece nad pacjentką. Jeśli będzie konieczne przekazanie opieki nad rodząca, personel winien ją o tym poinformować. Ciągłość opieki musi być zachowana ${ }^{53}$.

Kobieta w trakcie porodu, a także w gabinecie lekarskim podczas przyjęcia do szpitala ma prawo do obecności jednej bliskiej osoby (art. 21 u.p.p.). Osoba bliska ${ }^{54}$ może być obecna przy wszystkich zabiegach rodzącej. Należy podkreślić, że osoba bliska może towarzyszyć pacjentce również wtedy, gdy akcja porodowa nie odbywa się w sali do porodów rodzinnych, ale w sali wieloosobowej. Lekarz lub inna osoba

${ }^{48}$ Rozporządzenie Ministra Zdrowia z dnia 16 IX 2015 r., część IV.

${ }^{49}$ Rozporządzenie Ministra Zdrowia z dnia 16 IX 2015 r., część I pkt 12 ust. 2.

${ }^{50}$ Rozporządzenie Ministra Zdrowia z dnia 16 IX 2015 r., część I pkt 12 ust. 3.

${ }^{51}$ Rozporządzenie Ministra Zdrowia z dnia 16 IX 2015 r., część V pkt 1.

${ }^{52}$ Rozporządzenie Ministra Zdrowia z dnia 16 IX 2015 r., część V pkt 2 ust. 3.

${ }^{53}$ Rozporządzenie Ministra Zdrowia z dnia 16 IX 2015 r., część V pkt 3 ust. 1.

${ }^{54}$ Przez osobę bliską rozumie się małżonka, krewnego lub powinowatego do drugiego stopnia w linii prostej, przedstawiciela ustawowego, osobę pozostającą we wspólnym pożyciu lub osobę wskazaną przez pacjenta. 
wykonująca zawód medyczny ma prawo nie zgodzić się na obecność osoby bliskiej tylko i wyłącznie z dwóch powodów: w przypadku istnienia prawdopodobieństwa wystąpienia zagrożenia epidemicznego lub ze względu na bezpieczeństwo zdrowotne pacjenta. Akty wewnętrzne obowiązujące $\mathrm{w}$ placówkach medycznych, np. regulaminy, nie mogą zawierać regulacji sprzecznych z obowiązującymi Standardami albo ich rozszerzać. Pacjentka ma prawo wymagać, by akcji porodowej towarzyszył wyłącznie niezbędny personel (art. 22 ust. 2 u.p.p.). Rodząca musi wyrazić zgodę na obecność studentów, ${ }^{55}$.

Zgodnie ze Standardami opieki okołoporodowej personel szpitala ma obowiązek wspierać poród drogami natury przy minimum interwencji medycznych. Zgodnie z treścią Standardów muszą zaistnieć określone wskazania medyczne, by rozwiązać poród przez cesarskie cięcie. Personel medyczny powinien zachęcać rodzącą do aktywności fizycznej i pomagać jej w znajdywaniu optymalnych dla niej pozycji podczas całego porodu ${ }^{56}$. Podczas całej akcji porodowej rodząca ma prawo pić wodę oraz inne przejrzyste płyny ${ }^{57}$. Osoba sprawująca opiekę podczas porodu powinna przedstawić rodzącej pełną informację o niefarmakologicznych i farmakologicznych metodach łagodzenia bólów porodowych dostępnych w miejscu, w którym poród się odbywa. O tym, jakie metody dostępne są w danym szpitalu, rodząca powinna zostać poinformowana już na etapie przyjęcia do szpitala ${ }^{58}$. Zakładanie wkłucia do żyły obwodowej powinno nastąpić tylko i wyłącznie w sytuacji tego wymagającej ${ }^{59}$. Osoba sprawująca opiekę ma obowiązek chronić krocze rodzącej. Nacięcie krocza należy stosować tylko $\mathrm{w}$ medycznie uzasadnionych przypadkach i odnotowuje się to w dokumentacji medycznej ${ }^{60}$.

W każdym szpitalu kobieta ma prawo do opieki duszpasterskiej (art. 36 u.p.p.), a w przypadku pogorszenia stanu zdrowia lub zagrożenia życia szpital jest zobowiązany umożliwić pacjentce kontakt z duchownym jej wyznania, czego koszty ponosi szpital. W sytuacji niepowodzeń

${ }^{55}$ Wyjątkiem jest poród w szpitalu klinicznym tj. w szpitalu III - najwyższego poziomu referencyjnego, będącym bazą naukowo-dydaktyczną dla uczelni medycznej.

${ }^{56}$ Rozporządzenie Ministra Zdrowia z dnia 16 IX 2015 r., część V pkt 3 ust. 4.

${ }^{57}$ Rozporządzenie Ministra Zdrowia z dnia 16 IX 2015 r., część V pkt 3 ust. 5.

${ }^{58}$ Rozporządzenie Ministra Zdrowia z dnia 9 XI 2015 r. w sprawie standardów postępowania medycznego w łagodzeniu bólu porodowego (Dz.U. poz. 1997), Rozdział I, pkt 7.

${ }^{59}$ Rozporządzenie Ministra Zdrowia z dnia 16 IX 2015 r., część VIII pkt 2.

${ }^{60}$ Rozporządzenie Ministra Zdrowia z dnia 16 IX 2015 r., część IX pkt 4 ust. 7. 
położniczych lub w przypadku urodzenia noworodka o bardzo małej masie urodzeniowej, skrajnie niedojrzałego lub z wadą wrodzoną szpital jest zobowiązany do zapewnienia położnicy opieki psychologa ${ }^{61}$.

Po porodzie położnica ma prawo do instruktażu dotyczącego przystawienia noworodka do piersi oraz prawidłowej laktacji. W przypadku gdy osoba sprawująca opiekę nad pacjentką stwierdzi nieskuteczność karmienia piersia, powinna zdiagnozować problem i wdrożyć postępowanie zgodne $z$ aktualną wiedzą na temat laktacji, w celu umożliwienia skutecznego nakarmienia noworodka mlekiem matki, a jeżeli nie jest to możliwe - odciągniętym mlekiem matki. Karmienie noworodka mlekiem modyfikowanym bez wskazań medycznych i bez wyrażenia na to zgody matki jest niedopuszczalne. Matka ma prawo towarzyszyć noworodkowi podczas każdej czynności pielęgnacyjnej, szczepień oraz zabiegów. Wszelkie te czynności powinny zostać poprzedzone wyjaśnieniami, czego dotycza, a następnie powzięciem przez matkę zgody bądź nie na ich wykonanie ${ }^{62}$. Położnicy i jej dziecku należy zapewnić ciągłą profesjonalną opiekę w miejscu zamieszkania albo pobytu ${ }^{63}$. Położna powinna odwiedzić matkę z noworodkiem przynajmniej cztery razy.

\section{Gwarancje prawne stosowania standardów opieki okołoporodowej i mechanizmy ich kontroli}

Pomimo obowiązywania Standardów od 2012 r. sytuacja kobiet w Polsce w okresie okołoporodowym często znacznie odbiega od minimum wymogów ustanowionych w Rozporządzeniu. Wprawdzie dostrzegalne są pozytywne tendencje $\mathrm{w}$ zakresie realizacji podstawowych praw kobiet rodzących, jednak przeprowadzane analizy i raporty wciąż wykazują przykłady sytuacji świadczących o fundamentalnym łamaniu Standardów. Wiele placówek medycznych, nie biorąc pod uwagę charakteru normatywnego Standardów, uznaje je za niewiążące zalecenia i wytyczne. Wyniki raportów Najwyższej Izby Kontroli (NIK) i Fundacji Rodzić po Ludzku wskazują, że część placówek nawet nie próbowała wdrożyć obowiązujących Standardów. Zarówno Ministerstwo Zdrowia, jak i NFZ

${ }^{61}$ Rozporządzenie Ministra Zdrowia z dnia 16 IX 2015 r., część V pkt 3 ust. 5; Rozporządzenie Ministra Zdrowia z dnia 16 IX 2015 r., część XIV pkt 3.

${ }^{62}$ Artykuł 21 ust. 2 u.p.p. oraz \& 7 Rozporządzenia Ministra Zdrowia w sprawie obowiązkowych szczepień ochronnych z dnia 18 VIII 2011 r. (tekst jedn. Dz.U. 2018, poz. 753).

${ }^{63}$ Rozporządzenie Ministra Zdrowia z dnia 16 IX 2015 r., część XIV pkt 1. 
nie stworzyli żadnego systemu kontroli wdrażania Standardów i rozliczania osób odpowiedzialnych, tj. dyrektorów szpitali i ordynatorów za ich realizację w placówkach medycznych. W świetle powyższego, mimo obowiązywania Standardów, prawodawca nie zapewnił Standardom odpowiednich mechanizmów prawnych ich dostatecznego egzekwowania. W konsekwencji Standardy stanowią akt prawny, którego rzeczywiste stosowanie przez podmioty do tego zobowiązane należy ocenić jako niedostateczne.

Niestety, projekt nowego rozporządzenia wprowadzającego standard organizacyjny opieki okołoporodowej również nie został zaopatrzony w żadne mechanizmy kontroli jego realizacji. Akt prawny nie przewiduje mechanizmów egzekwowania treści obowiązków nałożonych na placówki medyczne od podmiotów za nie odpowiedzialnych. Bez wątpienia, stanowi to podstawowy mankament projektu nowej regulacji. W obecnie obowiązującym systemie opieki okołoporodowej, a także w modelu, który zacznie obowiązywać w 2019 r., jedyną możliwością dochodzenia praw przyznanych w Standardach przez poszkodowanego pacjenta jest pociągnięcie do odpowiedzialności personelu medycznego lub szpitala na zasadach ogólnych lub złożenie skargi do Rzecznika Praw Pacjenta ${ }^{64}$.

Biorąc pod uwagę, że Rozporządzenie, będące aktem wykonawczym u.d.l., zawiera przepisy regulujące postępowanie medyczne w zakresie opieki okołoporodowej, naruszenie tychże przepisów może stanowić naruszenie powszechnie obowiązującego prawa. Jak stanowi pkt 6 Postanowień ogólnych Rozporządzenia, "Odpowiedzialność prawną i zawodową osoby sprawującej opiekę za podejmowanie działania regulują przepisy ustawy z dnia 2 grudnia 2009 r. o izbach lekarskich oraz ustawy z dnia 1 lipca 2011 r. o samorządzie pielęgniarek i położnych" ${ }^{65}$. Prawodawca zdecydował się na powielenie przepisu w projekcie nowych standardów. Z tytułu odpowiedzialności zawodowej lekarz oraz położna odpowiadają za przewinienia będące nie tylko naruszeniem przepisów prawnych, ale również etyki zawodowej. Obowiązki zawodowe lekarzy i położnych w ramach opieki okołoporodowej należy traktować szeroko, jako wynikające z przepisów prawa i z istoty zawodu ${ }^{66}$. Należy zwrócić

${ }^{64}$ Złożenie skargi do Rzecznika Praw Pacjenta nie zostało wyrażone w treści Standardów, uprawnienie to wynika z Ustawy z dnia 6 XI 2008 r. o prawach pacjenta i Rzeczniku Praw Pacjenta (tekst jedn. Dz.U. 2017, poz. 1318, 1524, oraz Dz.U. 2018, poz. 1115).

${ }^{65}$ Rozporządzenie Ministra Zdrowia z dnia 16 IX 2015 r., część I pkt 6.

${ }^{66}$ D. Karkowska, op. cit., s. 32. 
uwagę, że wyżej wskazany pkt 6 Rozporządzenia nie oznacza, iż lekarz i położna podlegają wyłącznie odpowiedzialności zawodowej. Personel medyczny obecny przy porodzie za wszelką swą działalność oraz podjęte decyzje podlega także odpowiedzialności prawnej, zwłaszcza odpowiedzialności cywilnej i karnej, a w przypadku zatrudnionych również odpowiedzialności pracowniczej. W sytuacjach ciężkiego naruszenia praw kobiety rodzącej, w szczególności wtedy, gdy zachowanie personelu medycznego uchybia przepisom Rozporządzenia na zasadzie winy, możliwe jest, że lekarz lub położna będą pociągnięci do odpowiedzialności w sposób kumulatywny. Standardy opieki okołoporodowej, stanowiące prawo powszechnie obowiązujące, bezwzględnie zobowiązują lekarzy oraz położne do ich przestrzegania podczas udzielania świadczeń zdrowotnych.

Wedle praktycznych doświadczeń autorki zaledwie w jednostkowych, niezwykle rzadkich przypadkach pacjentki, wobec których personel medyczny nie przestrzegał Standardów, decydują się egzekwować swoje prawa, w tym występować z roszczeniami wobec personelu medycznego. O ile zdarza się, że kobiety składają skargę na personel do jego bezpośredniego przełożonego (często w sposób ustny, nieformalny), o tyle oficjalnych postępowań i procesów sądowych jest niewiele w stosunku do liczby przypadków nieprzestrzegania Standardów. Niestety, w dużej mierze kobiety dochodzą swoich praw i występują na drogę sądową wyłącznie w sytuacji poważnych niepowodzeń położniczych spowodowanych błędem lekarskim (np. upośledzenie czy śmierć dziecka). Jak pokazuje praktyka, wieloletnie, żmudne procesy często zniechęcają kobiety do walki o swoje prawa.

Gwarancje rzeczywistego realizowania standardów opieki okołoporodowej należy uznać za niewystarczające. Potwierdzają to pesymistyczne wyniki kontroli NIK oraz raport Fundacji Rodzić po Ludzku.

Na podstawie art. 2 ust. 1 Ustawy z dnia 23 grudnia 1994 r. o Najwyższej Izbie Kontroli ${ }^{67}$ Izba w okresie od 15 września 2015 r. do 22 stycznia 2016 r. podjęła się kontroli 24 publicznych zakładów opieki zdrowotnej, a w nich 25 oddziałów świadczących opiekę okołoporodową ${ }^{68}$. Kontrola

${ }^{67}$ Tekst jedn. Dz.U. 2017, poz. 524.

${ }^{68}$ Kontrolą objęto $6,4 \%$ oddziałów położniczych w Polsce. Dobierając oddziały położnicze do kontroli, uwzględniono wysoki odsetek cięć cesarskich oraz doniesienia medialne wskazujące na możliwość wystąpienia nieprawidłowości. Do kontroli wybrano też osiem szpitali skontrolowanych w 2009 r. w celu sprawdzenia wykonania wniosków pokontrolnych. W kontroli uczestniczyło osiem delegatur NIK. 
"Opieka okołoporodowa na oddziałach położniczych" (P/15/0650) była kontrolą koordynowaną dotyczącą lat 2013-2015, ujętą w planie pracy NIK, podjętą zgodnie z sugestią Szefa Kancelarii Prezesa Rady Ministrów $^{69}$. Jako cel główny kontroli wskazano ocenę działalności oddziałów położniczych w zakresie opieki okołoporodowej, a do celów szczegółowych należała ocena:

1. przygotowania oddziałów położniczych do udzielania świadczeń zdrowotnych w sposób wynikający z przepisów prawa i zapewniający pacjentom opiekę zgodną ze standardami opieki okołoporodowej i prawami pacjenta;

2. przestrzegania standardów opieki okołoporodowej i prawa pacjenta;

3. oferowania przez szpital odpłatnych usług medycznych związanych z porodem;

4. realizacji wniosków po wcześniejszych kontrolach $\mathrm{NIK}^{70}$.

Wyniki kontroli przeprowadzonej przez NIK należy uznać za negatywne. Skontrolowane oddziały położnicze nie zapewniały pacjentkom i noworodkom wymaganej jakości świadczeń medycznych, które przysługują im na podstawie Standardów oraz przepisów z zakresu praw pacjenta. W świetle powyższego należy stwierdzić, że obowiązujące przepisy Standardów nie są wystarczającym narzędziem prawnym do zapewnienia kobietom oraz noworodkom postulowanego minimum praw, a w szczególności poszanowania intymności i godności. Pomimo że kontrola NIK wykazała liczne nieprawidłowości, odnotowano spadek umieralności wśród niemowląt. Uzyskano więc poprawę wskaźnika w stopniu określonym w Narodowym Programie Zdrowia na lata 20072015, co niewątpliwe należy uznać za pozytywny efekt obowiązywania Rozporządzenia, a także ogólnego podnoszenia się poziomu wiedzy i opieki medycznej.

Fundacja Rodzić po Ludzku wydała w 2018 r. raport z monitoringu oddziałów położniczych "Opieka okołoporodowa kobiet w świetle doświadczeń kobiet" ${ }^{\prime \prime 1}$. W Raporcie zostały przedstawione doświadczenia prawie 9 tys. kobiet, które urodziły dziecko w okresie od stycznia 2017 r.

${ }^{69}$ Informacja o wynikach kontroli NIK, Opieka okołoporodowa na oddziałach położniczych, LBI.410.008.2015, Nr ewid. 203/2015/P/15/065/LBI.

${ }^{70}$ Ibidem.

${ }^{71}$ Raport z monitoringu oddziałów położniczych pt. „Opieka okołoporodowa kobiet ws świetle doświadczeń kobiet", pod red. I. Adamskiej-Sali, J. Pietrusiewicz, Warszawa 2018, dalej "Raport". 
do marca 2018 r. ${ }^{72}$ Podobnie jak w przypadku wyników kontroli przeprowadzonej przez NIK, Fundacja również oceniła realizację Standardów jako niedostateczna, wykazując liczne uchybienia i przedstawiając druzgocące statystyki. W Raporcie podkreślono, że pomimo pozytywnych zmian, jakie dokonały się w opiece okołoporodowej w Polsce, wiele kobiet nadal doświadcza złego traktowania, lekceważenia oraz obraźliwych zachowań ze strony personelu medycznego ${ }^{73}$. Wedle analizy dokonanej przez Fundację pomimo obowiązujących Standardów od lat łamane są podstawowe prawa i ograniczane wolności człowieka podczas opieki okołoporodowej.

Z Raportu wynika, że pacjentki w wielu placówkach położniczych nie mogą korzystać z przyznanych im praw. Przykładowo, nieustannie jest ograniczana aktywność kobiety podczas porodu. Wiele kobiet wedle bezwzględnych zaleceń personelu medycznego musi leżeć podczas porodu, nie może samodzielnie wybrać wygodnej pozycji do rodzenia ${ }^{74}$. Należy podkreślić, że jednym z ważniejszych celów Standardów jest obniżenie medykalizacji porodu fizjologicznego. Pomimo obowiązywania przepisów poziom medykalizacji porodu fizjologicznego na terenie kraju wciąż jest bardzo wysoki. Wedle Fundacji prawdopodobnie wynika to $\mathrm{z}$ faktu, że Standardy ciągle jeszcze nie są w pełni wdrożone w szpitalach, a potrzeby kobiet w zakresie minimalizowania medykalizacji są często ignorowane ${ }^{75}$.Wyniki przeprowadzonej analizy potwierdzają, że w wielu placówkach położniczych nadal obecne są szkodliwe procedury i przestarzałe rutyny, np. rutynowe zakładanie wkłucia do żyły obwodowej, nawet gdy nie ma medycznego uzasadnienia podjęcia tej czynności, indukcja porodu, przyśpieszanie porodu za pomocą kroplówki z oksytocyna, wykonywanie cesarskiego cięcia w sytuacjach klinicznych tego niewymagających, nacinanie krocza, ograniczanie aktywności, rodzenie dziecka w niefizjologicznej pozycji, przerywanie kontaktu matki $\mathrm{z}$ dzieckiem po narodzinach $\mathrm{w}$ celu zmierzenia i zważenia noworodka, czy też podawanie mleka modyfikowanego bez wcześniejszej zgody matki ${ }^{76}$. W tym okresie $4,3 \%$ kobiet doświadczyło poważnych nadużyć lub przemocy związanych z zachowaniem personelu lub niedopełnieniem wszystkich procedur; $15,5 \%$ badanych uznało,

\footnotetext{
${ }^{72}$ Ibidem, s. 8.

${ }^{73}$ Ibidem.

${ }^{74}$ Ibidem, s. 23.

${ }^{75}$ Ibidem.

${ }^{76}$ Ibidem.
} 
że podczas pobytu w szpitalu zostało złamane jakieś podstawowe ich prawo. Jedynie 3\% złożyło skargę w sprawie, w której nastąpiło, według nich, naruszenie prawa ${ }^{77}$.

\section{Analiza projektu rozporządzenia wprowadzającego standard organizacyjny w zakresie opieki okołoporodowej}

Biorąc pod uwagę pesymistyczne raporty dotyczące opieki okołoporodowej w Polsce, wiele środowisk związanych z opieką okołoporodową lobbowało na rzecz nowelizacji obowiązujących Standardów, wnioskując przede wszystkim o wzmocnienie mechanizmów kontroli przestrzegania prawa. Ponadto, na podstawie zdobytych doświadczeń oraz zdiagnozowanych problemów i nowych wskazań postępowania medycznego w opiece okołoporodowej, wnoszono o dokonanie pewnych zmian w treści Standardów. W obliczu nieprzestrzegania podstawowych praw kobiet w placówkach medycznych i konieczności wprowadzenia zmian w prawie niezrozumiała wydaje się próba całkowitej likwidacji Standardów jako powszechnie obowiązującego prawa, zaproponowana przez Ministra Zdrowia K. Radziwiłła w 2016 r.

Ustawa z dnia 10 czerwca 2016 r. o zmianie ustawy o działalności leczniczej oraz niektórych innych ustaw ${ }^{78}$ likwiduje wypracowane przez Zespół Ekspertów Z. Religi standardy postępowania medycznego dotyczące porodu fizjologicznego, a także standardy dotyczące łagodzenia bólu w trakcie porodu, postępowania w ciąży powikłanej, określonych patologiach i niepowodzeniach położniczych. Standardy opieki okołoporodowej w niezmienionej wersji będą obowiązywały co najwyżej do 31 grudnia 2018 r. Omawiane zmiany na etapie prac nad projektem rozporządzenia nie były konsultowane $\mathrm{z}$ żadnym środowiskiem zaangażowanym w opiekę okołoporodową ${ }^{79}$.

Propozycję zmian w prawie zgłosiła Naczelna Rada Lekarska, która postulowała wykreślenie upoważnienia ustawowego do określania przez Ministra Zdrowia jakichkolwiek standardów, podnosząc, że

77 Ibidem, s. 26.

${ }^{78}$ Dz.U. poz. 960.

${ }^{79}$ Stanowisko Fundacji Rodzić po Ludzku w sprawie zmian dotyczacych Standardów opieki okołoporodowej, http://www.rodzicpoludzku.pl/Interwencje/Stanowisko-Fundacji-Rodzic-po-Ludzku-w-sprawie-zmian-dotyczacych-Standardow-opieki-okoloporodowej. html (dostęp: 11 VII 2017). 
stanowi ono "jaskrawe i nieuprawnione wkroczenie władzy ustawodawczej i administracyjnej w autonomiczny obszar nauki i wiedzy"80. Jak twierdził M. Hemankiewicz, prezes Naczelnej Rady Lekarskiej, „Minister nie powinien narzucać standardów, mogą to robić tylko towarzystwa naukowe. Poza tym standardy mają swoje wady, bo zdarzają się przypadki, w których dla dobra pacjenta nie można ich zastosować. Jeśli standardy mają rangę obowiązujących przepisów, lekarz może mieć z tym kłopoty" ${ }^{\prime \prime}$. Przedstawiciele Naczelnej Rady Lekarskiej stanęli na stanowisku, że standardy opieki okołoporodowej nie powinny mieć formy powszechnie obowiązującego aktu normatywnego, ale powinny obrać kształt niewiążących zaleceń, których realizacja nie może być prawnie egzekwowana.

Począwszy od czerwca 2016 r., na zaproszenie Ministerstwa Zdrowia, odbyły się co najmniej dwa spotkania zespołu ekspertów dotyczące efektywności wdrażania Standardów opieki okołoporodowej, choć jak twierdzi przedstawiciel Fundacji Rodzić po Ludzku, "W tym czasie los Standardów był już z góry przesądzony" ${ }^{\prime \prime 2}$. Według informacji podanych przez Fundację Ministerstwo Zdrowia zataiło informacje o projektowanych zmianach w ustawie przed zespołem ekspertów, w skład którego wchodzili Krajowi Konsultanci do spraw ginekologii i położnictwa, perinatologii, neonatologii, pielęgniarstwa ginekologicznego i położniczego, epidemiolodzy, prawnicy i przedstawiciele organizacji pozarządowych ${ }^{83}$. Ministerstwo Zdrowia oświadczyło jednak, że projekt ustawy o zmianie ustawy o działalności leczniczej oraz niektórych innych ustaw był konsultowany z 59 organizacjami społecznymi ${ }^{84}$.

${ }^{80}$ Likwidacja Standardów Opieki Okołoporodowej. Wyjaśnienia Ministerstwa Zdrowia, „Interia”, 22 II 2017 r., http://fakty.interia.pl/raporty/raport-opieka-okoloporodowa/opieka-okoloporodowa/news-likwidacja-standardow-opieki-okoloporodowej-wyjasnieniamini,nId,2356541 (dostęp: 11 VII 2017).

${ }^{81} \mathrm{~J}$. Watoła, Poród znowu bez standardów? Ministerstwo zmienia przepisy. ",To cofnie położnictwo do PRL", "Gazeta Wyborcza", 12 XII 2016 r., http://wyborcza.pl/7,75398,21110334,porod-znowu-bez-standardow-ministerstwo-zmienia-przepisy-to.html (dostęp: 11 VII 2017).

${ }^{82}$ Jak twierdzą przedstawiciele Fundacji Rodzić po Ludzku, nikt z Ministerstwa Zdrowia nie poinformował o zmianach w ustawie, mimo że jeszcze we wrześniu Fundacja otrzymała pismo z Ministerstwa podtrzymujące celowość istnienia Standardów.

${ }^{83}$ Ibidem.

${ }^{84}$ Likwidacja Standardów Opieki Okołoporodowej. Wyjaśnienia Ministerstwa Zdrowia, https://fakty.interia.pl/raporty/raport-opieka-okoloporodowa/opieka-okoloporodowa/ news-likwidacja-standardow-opieki-okoloporodowej-wyjasnienia-mini,nId,2356541 (dostęp: 21 VII 2018). 
Pierwotnie planowane zmiany w prawie, za którymi lobbowała Naczelna Rada Lekarska, mogły pociągnąć za sobą poważne skutki zarówno dla pacjentek, jak i dla samych lekarzy oraz położnych. Z prawnego punktu widzenia usunięcie jednolitych standardów, stanowiących powszechnie obowiązujący akt prawny, mogło spowodować w odniesieniu do pacjentek znaczne osłabienie ochrony prawnej. Kobiety nie miałyby pewności, że pewne minimum standardów będzie dostępne w każdej placówce na terenie Polski. Niewątpliwie, jakość opieki, jaką otrzymałaby rodząca, uległaby obniżeniu, gdyż byłaby zależna od decyzji ordynatora lub lekarza, zwyczajów i rutyny panującej w danej placówce. $Z$ drugiej strony, brak Standardów wpłynąłby w pewien sposób również na niekorzyść lekarzy i położnych. Przestrzeganie Standardów przez podmiot wykonujący działalność leczniczą stanowi rodzaj ochrony przed nieuzasadnionymi roszczeniami cywilnoprawnymi ze strony pacjentki w zakresie jakości świadczeń zdrowotnych.

Ministerstwo Zdrowia stwierdziło, że niczego nie zataiło, gdyż prace nad zmianą ustawy o działalności leczniczej można było śledzić na stronie Rządowego Centrum Legislacji. Według Ministerstwa "Zmiana ma charakter porządkujący. Została wprowadzona z uwagi na to, że standardy medyczne - jako zbiory rekomendacji (zaleceń), które odnoszą się do określonych działań w obszarze medycyny - nie powinny mieć charakteru prawnego, a co za tym idzie, nie powinny stanowić bezwzględnie obowiązującego prawa" ${ }^{\prime \prime}$. Planowano, by na podstawie wprowadzanych zmian w prawie Minister Zdrowia ogłosił w formie obwieszczenia zalecenia postępowania w zakresie opieki okołoporodowej, przygotowywane przez towarzystwa naukowe (co potwierdza, że Ministerstwo planowało odejść od formy rozporządzenia na rzecz niewiążącego prawnie obwieszczenia) ${ }^{86}$. Możliwość taką miał zapewnić m.in. rządowy projekt ustawy o zmianie ustawy o świadczeniach opieki zdrowotnej finansowanych ze środków publicznych (druk nr 1098), który z dniem 10 lutego 2017 r. został przekazany Prezydentowi i Marszałkowi Senatu. Zgodnie z projektem Minister Zdrowia, po zasięgnięciu opinii Agencji Oceny Technologii Medycznych i Taryfikacji, miał ogłosić, w formie obwieszczenia ogłaszanego w Dzienniku Urzędowym Ministra Zdrowia, zalecenia postępowania dotyczące diagnostyki i leczenia w zakresie świadczeń finansowanych ze środków publicznych,

\footnotetext{
${ }^{85}$ Ibidem.

${ }^{86}$ Ibidem.
} 
odrębnie dla poszczególnych dziedzin medycyny, opracowane przez odpowiednie stowarzyszenia będące zgodnie z postanowieniami ich statutów towarzystwami naukowymi o zasięgu krajowym, zrzeszające specjalistów w danej dziedzinie medycyny ${ }^{87}$.

Środowisko pacjentek, z Fundacją Rodzić po Ludzku na czele, krytycznie odniosło się do projektowanych zmian. W styczniu 2017 r. Fundacja złożyła petycję "Obywatele w obronie Standardów Opieki Okołoporodowej", która została podpisana przez prawie 80 tys. osób, przy znacznym zaangażowaniu wielu organizacji oraz mediów. Wątpliwości prawników i Fundacji rodziły następujące zagadnienia prawne w zakresie zmian proponowanych przez resort zdrowia:

1. czy wypracowane przez zespół ekspertów i obecnie obowiązujące standardy opieki okołoporodowej zostaną uwzględnione w nowej regulacji prawnej, która na podstawie nowego brzmienia art. 22 ust. 5 u.d.l. ma nie stanowić już procedury postępowania medycznego, ale ma być wydane $\mathrm{w}$ formie standardów organizacyjnych, zapewne w drodze obwieszczenia;

2. czy standardy opieki okołoporodowej, jeśli zostaną zachowane $\mathrm{w}$ podobnym kształcie jak obecnie obowiązujące, mające stricte medyczny charakter, mogą zostać wydane w rozporządzeniu będącym już wyłącznie standardem organizacyjnym (a nie standardem postępowania medycznego) i jeśli odpowiedź na pytanie będzie twierdząca, to czy taka konstrukcja prawna będzie legalna.

W związku ze wskazanymi wątpliwościami oraz zapewnieniami Ministerstwa Zdrowia o rzekomo sporządzonej opinii prawnej w zakresie Standardów Fundacja Rodzić po Ludzku w dniu 23 stycznia 2017 r. złożyła na ręce Ministra Zdrowia K. Radziwiłła pismo zawierające wniosek o udzielenie informacji publicznej w zakresie udostępnienia treści rzeczonej opinii prawnej oraz wskazania trybu jej sporządzenia i podmiotów ją opracowujących ${ }^{88}$. W związku z brakiem ustosunkowania się do wyżej wskazanego wniosku przez Ministra Zdrowia, z dniem 7 marca 2017 r. Fundacja złożyła skargę na bezczynność Ministra Zdrowia do Wojewódzkiego Sądu Administracyjnego w Warszawie ${ }^{89}$. W reakcji na

87 Ibidem.

${ }^{88}$ Pismo Fundacji Rodzić po Ludzku z dnia 23 I 2017 r. skierowane do Ministra Zdrowia K. Radziwiłła, http://www.rodzicpoludzku.pl/images/rzecznictwo/23.01_pismo_ws_analizy_prawnej_DIP.pdf (dostęp: 15 VII 2018).

${ }^{89}$ Skarga Fundacji Rodzić po Ludzku na bezczynność Ministra Zdrowia z dnia 7 III 2017 r., http://www.rodzicpoludzku.pl/images/rzecznictwo/Skarga_na_bezczynnosc_ Mz_analiza_prawna_07.03.17.pdf (dostęp: 15 VII 2018). 
skargę Minister odpowiedział 22 marca 2017 r., iż w ocenie Ministerstwa uwzględnienie obecnie obowiązujących standardów opieki okołoporodowej będzie możliwe w projektowanym nowym rozporządzeniu, pomimo że nie będzie ono już jak dotąd stanowić standardów postępowania medycznego. Ponadto Ministerstwo stwierdziło, że analiza prawna wskazanego zagadnienia miała "charakter roboczy" i nie została sporządzona $\mathrm{w}$ formie dokumentu, dlatego też nie jest możliwe jej udostępnienie ${ }^{90}$.

W efekcie bardzo dużej krytyki postępowania Ministerstwa Zdrowia mającego na celu wygaszenie Standardów Minister Zdrowia złożył publiczną obietnicę, że sytuacja związana z prawami kobiet w opiece okołoporodowej nie pogorszy się, a także obiecał, że prawa kobiet $\mathrm{z}$ zakresu opieki okołoporodowej nadal będą regulowane $\mathrm{w}$ formie rozporządzenia. W związku z tym na początku 2017 r. powołał zespół ds. opracowania projektu rozporządzenia standardów organizacyjnych opieki zdrowotnej sprawowanej nad kobietą w fizjologicznej ciąży, fizjologicznego porodu, połogu oraz opieki nad noworodkiem. W dniu 4 kwietnia 2018 r. resort zdrowia przedstawił nowy projekt rozporządzenia w sprawie standardu organizacyjnego opieki okołoporodowej ${ }^{91}$. Dzięki pracy zespołu, a w szczególności dzięki naciskom Fundacji Rodzić po Ludzku, do projektu nowych organizacyjnych standardów opieki okołoporodowej zostały wprowadzone nowe postanowienia dotyczące m.in.:

1. wykonywania badań przesiewowych dotyczących ryzyka wystąpienia depresji w ciąży i depresji poporodowej;

2. prawa ciężarnej do wypełniania dokumentacji medycznej w wybranej przez siebie placówce przed porodem (a nie podczas przyjęcia do placówki medycznej lub w czasie porodu);

3. obowiązku lekarza do skierowania kobiety do położnej POZ na edukację przedporodowa, czyli tzw. szkołę rodzenia, oraz ustalenia zakresu tematycznego edukacji przedporodowej;

4. w treść nowych organizacyjnych standardów wpisano częściowo zapisy z innych rozporządzeń, np. łagodzenie bólu czy postępowanie

${ }^{90}$ Odpowiedź Ministra Zdrowia na skargę na bezczynność organu z dnia 22 III 2017 r., http://www.rodzicpoludzku.pl/images/rzecznictwo/20.03_odpowiedz_Mz_ws_DIP. pdf (dostęp: 15 VII 2018).

${ }^{91}$ Projekt rozporządzenia Ministra Zdrowia w sprawie standardu organizacyjnego opieki okołoporodowej z dnia 4 IV 2018 r. (w wykazie prac Ministra Zdrowia nr MZ621), https://legislacja.rcl.gov.pl/projekt/12310054/katalog/12499721\#12499721 (dostęp: 15 VII 2018). 
w trakcie niepowodzeń położniczych, które zmieniło swoją nazwę na „postępowanie w sytuacjach szczególnych, tj.: poronienie, poród dziecka chorego lub martwego";

5. obowiązku personelu medycznego respektowania planu porodu;

6. promocji karmienia piersia, w tym zobowiązania placówek medycznych do posiadania sprzętu do odciągania pokarmu i zagwarantowania kobietom, które nie mogą z określonych powodów nakarmić dziecka swoim pokarmem, mleka z banku mleka;

7. zobowiązania kierowników placówek do zapoznawania swoich pracowników z przepisami prawnymi dotyczącymi standardów opieki okołoporodowej.

Projekt nowego rozporządzenia został przesłany 66 organizacjom do opinii i konsultacji społecznych. Wyniki konsultacji zostały opublikowane 25 czerwca 2018 r. Obecnie prace nad projektem rozporządzenia nadal trwaja, a Resort Zdrowia analizuje przesłane opinie podmiotów zewnętrznych w zakresie wprowadzenia nowych standardów opieki okołoporodowej. Najprawdopodobniej wkrótce odniesie się do wniesionych uwag.

\section{Podsumowanie}

Standardy postępowania z zakresu wykonywania świadczeń medycznych, które zostały opracowane przez uznanych ekspertów na podstawie aktualnej wiedzy medycznej i przeprowadzanych badań, są nie do przecenienia we współczesnej medycynie. Dzięki obowiązywaniu standardów postępowania personel medyczny wie, jak powinien się zachować w określonej sytuacji klinicznej, dzięki czemu w wielu przypadkach może uniknąć popełnienia błędu medycznego. Dlatego też standardy postępowania powinny stanowić nie tylko przedmiot zainteresowania ich bezpośrednich beneficjentów, ale w szczególności personelu medycznego, który prawnie odpowiada za ewentualne przypadki postępowania niezgodnego z lege artis.

Obowiązywanie standardów postępowania w głównych dziedzinach medycyny stanowi również wyraz realizacji podstawowych praw pacjenta. W przypadku sprawowania opieki okołoporodowej powołanie jednolitych standardów postępowania medycznego niewątpliwie przyczyniało się do ustanowienia pewnego minimum, na które mogła się powołać każda kobieta w Polsce (funkcja stabilizująca prawa). Standardy 
zostały wydane w formie aktu prawnego o randze rozporządzenia, czyli aktu powszechnie obowiązującego. Oznacza to, że w sytuacji fizjologicznej ciąży i fizjologicznego porodu prawa przysługujące kobietom powinny być realizowane w sposób jednakowy we wszystkich placówkach medycznych w Polsce - zarówno publicznych, jak i niepublicznych. Poprzez obowiązywanie jednolitych standardów każda pacjentka może zapoznać się z prawami, jakie jej przysługuja, może świadomie uczestniczyć w porodzie, wiedząc, czego może wymagać od szpitala i personelu medycznego. Powszechne obowiązywanie Standardów miało wykluczać zachowania zagrażające pewnym szczególnie chronionym wartościom (np. naruszeniom godności czy prywatności) oraz intensyfikować działania sprzyjające ochronie tychże wartości (funkcja ochronna prawa). Niewątpliwie, Standardy promowały również pozytywne zmiany i rozwój w placówkach medycznych w zakresie opieki okołoporodowej (funkcja dynamizująca prawa).

Ponadto należy wskazać, że Standardy mogą być też narzędziem edukacyjnym zarówno w stosunku do personelu medycznego, jak i do pacjentek (funkcja wychowawcza prawa). Standardy wyznaczają lekarzom, pielęgniarkom i położnym standardowe modele zachowania i formułują wytyczne zgodne z aktualną wiedzą medyczną oraz deontologią zawodową. Pacjentki mogą natomiast znaleźć w treści Standardów spis i harmonogram szeregu czynności, które w czasie ciąży, porodu i połogu powinna wykonać każda kobieta lub których wykonania powinna oczekiwać od personelu medycznego.

Mimo niezaprzeczalnie pozytywnej i doniosłej roli, jaką pełnią Standardy, ich przepisy nie były w Polsce powszechnie przestrzegane. Wyniki badań przeprowadzonych przez niezależne od siebie podmioty wskazują, że pomimo wielu zadowalających zmian, które są efektem wdrażania Standardów, kobiety nadal doświadczają sytuacji uwłaczających ich godności, czy też pozostających w sprzeczności z ich oczekiwaniami, a przede wszystkim w sprzeczności z obowiązującym prawem. Ponadto, jak pokazała praktyka, treść Standardów miała zbyt wiele luk prawnych, które pozwalały szpitalom na niestosowanie pewnych wymogów, czego przykładem było chociażby wykorzystywanie programów dostosowawczych do nieprzystosowywania sal porodowych i poporodowych do obowiązujących wytycznych. Wiele placówek traktowało Standardy jako niewiążące zalecenia i uporczywie łamało prawa pacjentek, często nie ponosząc z tego tytułu odpowiednich konsekwencji prawnych. Dlatego też należy stwierdzić, że podstawowym mankamentem Standardów jest 
brak ustanowienia prawnych mechanizmów egzekwowania obowiązujących przepisów w zakresie opieki okołoporodowej.

Zmiany, jakie zostaną wprowadzone w opiece okołoporodowej najpóźniej od dnia 1 stycznia 2019 r., są jednak niepokojące. Standardy postępowania medycznego zostaną zastąipione standardami organizacyjnymi w opiece okołoporodowej, co pierwotnie miało być podstawą próby degradacji standardów opieki okołoporodowej do rangi niewiążącego prawnie obwieszczenia Ministra Zdrowia. Chociaż ostatecznie standardy zostaną utrzymane $\mathrm{w}$ randze rozporządzenia, forma ich obowiązywania nadal budzi wątpliwości prawne $w$ aspekcie techniki prawodawczej. Należy bowiem zwrócić uwagę, że zgodnie z projektem nowych standardów w znacznej mierze powielają one treść swojego bezpośredniego poprzednika. W świetle powyższego zmiana formy ze standardów postępowania medycznego na standardy organizacyjne jest prawnie niezrozumiała. Podkreślenia wymaga również okoliczność, że w projekcie nowych standardów wytyczne i zalecenia nadal mają ściśle medyczny charakter, dlatego też powinny być ustanowione, jak poprzednio, $\mathrm{w}$ formie standardów postępowania medycznego. Nowa forma ukształtowania standardów budzi liczne wątpliwości natury prawnej, dlatego działanie prawodawcy nie znajduje raczej racjonalnego wyjaśnienia.

Standardy opieki okołoporodowej w Polsce wymagają zasadniczych zmian, zwłaszcza w zakresie wprowadzenia gwarancji, by egzekwowanie obowiązujących przepisów było prawnie możliwe oraz bardziej dostępne dla ewentualnych poszkodowanych. Standardy powinny odzwierciedlać realne potrzeby kobiet w Polsce oraz odpowiadać aktualnej wiedzy medycznej w tym zakresie. Niestety, projekt nowych standardów nie przynosi odpowiedzi na podstawowe problemy w zakresie opieki okołoporodowej. Biorąc pod uwagę powyższe, należy się przychylić do obaw kobiet, organizacji je wspierających oraz Rzecznika Praw Obywatelskich, że zmiana dotychczas obowiązującej formy standardów opieki okołoporodowej może spowodować pogorszenie, i tak nie zawsze dobrej, sytuacji kobiet na oddziałach położniczych w Polsce. Dlatego też wysoce pożądany byłby powrót do uprzednio obowiązującego stanu prawnego, w którym standardy opieki okołoporodowej stanowiły akt normatywny w postaci powszechnie obowiązujących wytycznych postępowania medycznego. Nie zmienia to jednak faktu, że treść standardów opieki okołoporodowej powinna zostać znowelizowana, tak by uwzględniała uwagi i wnioski kontroli przeprowadzonej przez NIK oraz spostrzeżenia organizacji pozarządowych przedstawianych w raportach, 
a także analizy środowisk akademickich w zakresie dostosowania treści standardów do aktualnej wiedzy medycznej i potrzeb kobiet w Polsce. Przede wszystkim jednak nowy akt prawny powinien zostać zaopatrzony w zespół mechanizmów prawnych, który przyczyniłby się do zagwarantowania rzeczywistej realizacji standardów opieki okołoporodowej przez placówki medyczne na terenie kraju. Ustawodawca powinien wyraźnie wskazać, jakie konsekwencje prawne poniesie placówka medyczna, która nie będzie przestrzegać poszczególnych przepisów Rozporządzenia (zasady odpowiedzialności placówki medycznej). Konieczna wydaje się również regulacja odpowiedzialności personelu medycznego z tytułu odmowy egzekwowania Standardów lub naruszenia obowiązków, które Rozporządzenie nakłada na pracowników placówek położniczych (zasady odpowiedzialności personelu medycznego). W końcu niezwykle ważne wydaje się ustalenie jednakowych procedur dochodzenia swoich praw przez pacjentki w przypadku ich naruszenia przez szpital lub personel medyczny (gwarancje proceduralne). Uwzględnienie wyżej wskazanych regulacji z pewnością przyczyniłoby się do uzyskania przez kobiety w Polsce pewności, że standardy opieki okołoporodowej stanowią zespół fundamentalnych praw, które w sposób bezwzględny i jednakowy będą realizowane w każdej placówce położniczej na terenie kraju.

\section{LEGAL REGULATIONS CONCERNING PERINATAL CARE IN POLAND IN THE CONTEXT OF THE DRAFT OF A NEW ORGANISATIONAL STANDARD}

\section{Su m mary}

Pursuant to Article 68(3) of the Constitution of the Republic of Poland, a pregnant woman is entitled to special care from the State. Therefore, it seems extremely important to indicate uniform, universally binding standards in order to improve the quality of services provided and to respect the fundamental rights due to women and their children in maternity care. Unfortunately, as the analysis and reports concerning the observance of patients' rights during the perinatal period show, the current standards are not always properly implemented by medical institutions, and the legal guarantees of observance of perinatal care standards are not sufficient.

The aim of the article is to discuss the legal regulations in force in the field of perinatal care, to indicate their subject and subject scope and to conduct a legal analysis of the proposal of new organisational standards of perinatal care, which are to enter into force as of 1 January 2019. The basis for the discussion is the presentation of the legal form of the existing standards of perinatal care. It is extremely 
important to answer the question whether the principles of medical knowledge should be enacted in the form of standards of medical procedure in the form of universally binding normative act, or whether they should constitute guidelines and recommendations that are legally non-binding. Perinatal care standards in the context of the duty of doctors and medical staff to apply current medical knowledge and to act with due diligence deserves additional attention. The article contains a detailed analysis of the proposal of new standards and presents de lege ferenda postulates, especially in the field of legal guarantees of observance of perinatal care standards in Poland.

Keywords: perinatal care standards - perinatal care - medical management standards - patient's rights 